\title{
TANGGUNG JAWAB BANK DALAM PENGGUNAAN COMMERCIAL PAPER SEBAGAI SUMBER PENDANAAN PERUSAHAAN
}

\author{
Kingkin Wahyuningdiah
}

\begin{abstract}
ABSTRAK
Commercial Paper (CP) merupakan salah satu jenis surat berharga yang dapat dimanfaatkan sebagai sumber pembiayaan perusahaan, di samping sumber pembiayaan lainnya. Proses penerbitan dan perdagangan CP mengacu pada Keputusan Direksi Bank Indonesia No.28/32/KEP/DIR dan Surat Edaran Bank Indonesia No.28/49/UPG Pihak yang terlibat dalam penerbitan CP meliputi bank, baik sebagai pengatur penerbitan, agen penerbitan dan agen pembayar. Ketentuan dalam surat edaran ini ternyata tidak sejalan dengan ketentuan KUHD mengenai hal yang sama, yang menganggap semua pihak yang terdapat tandatangannya dalam surat berharga merupakan debitur, dan oleh karenanya turut bertanggungjawab terhadap pembayaran sural berharga dimaksud.
\end{abstract}

\section{Kata Kunci: Commercial Paper, Tanggung jawab Bank, Pendanaan Perusahaan}

\section{A. PENDAhuluan}

Perusahaan merupakan salah satu institusi, di mana masyarakat melakukan kegiatan usaha di bidang ekonomi. Definidsi perusahaan dapat ditemukan dalam Undang-undang No. 3 Tahun 1992 Tentang Wajib Daftar Perusahaan, Pasal 1 huruf (b). Menurut Abdulkadir (2005:9), berdasarkan sefinisi tersebut, setiap perusahaan memiliki bentuk usaha yang disebut badan usaha dan jenis usaha yaitu menjalankan kegiatan di bidang ekonomi secara terus menerus dengan tujuan memperoleh keuntungan dan atau laba. Untuk mencapai tujuan Menurut P.F. Droker sebagaimana dikutip Sri Redjeki Hartono ${ }^{1}$ perusahaan harus dapat melaksanakan fungsinya, dan fungsi pokok dari perusahaan adalah pemasaran dan pembaharuan. Dalam menjalankan fungsi pokok tersebut, perusahaan akan menghadapi dua keadaan yang berbeda, yaitu mendapatkan pemasukan dari hasil usahanya dan memerlukan pengeluaran sebagai biaya perusahaan.

Masalah pembiayaan perusahaan dalam perusahaan dikenal dengan istilah pembelanjaan. Dalam arti sempit merupakan aktifitas yang hanya bersangkutan dengan masalah usaha mendapatkan dana saja, yang sering disebut

\footnotetext{
Sri Redjeki Hartono. 1997. Hukum Asuransi dan Perusahaan Asuransi. Grafika, Jakarta, him. 4
}

dengan istilah pembelanjaan pasif atau pendanaan (financing). Untuk mendukung aktivitas-aktivitas perusahaan agar dapat dilakukan dengan baik, maka biasanya diperlukan untuk menggali dana eksteren (dana dari luar) perusahaan (Manulang, 1994:209). Untuk membantu pendanaan bagi perusahaan, perbankan akan mendorong pihak lain untuk ikut menanggung hutang, dengan harapan bahwa bank dapat menarik keuntungan dalam bentuk imbalan jasa peminjaman-peminjaman tersebut, perkembangan semacam ini disebut dengan istilah disintermediation ${ }^{2}$. Dalam kegiatan ini bank melibatkan investor untuk meminjamkan dananya kepada pihak yang membutuhkannya, sedangkan bank hanya bertindak sebagai penghubung antara para pemilik dana dan pihak yang membutuhkan dana tersebut. Salah satu bentuk yang dapat ditempuh untuk melaksanakan kegiatan semacam itu adalah dengan melakukan penerbitan dan penjualan Commercial Paper (selanjutnya disingkat $(P)$, yang selama ini telah dikenal dan digunakan di luar negeri sebagai alternatif pendanaan perusahaan. Untuk melakukan penerbitan dan perdagangan $\mathrm{CP}$ tersebut, tentu saja akan melibatkan investor sebagai calon pembeli CP dan bank sebagai pihak yang akan

\footnotetext{
- Nono Anwar Makarim. 1993 Aspek Hukum Commercial Paper di Indonesia. Makalah pada seminar Nasional Tentang Tinjauan Hukum Atas Commercial Paper. Diselenggarakan di Semarang., hlm. 7 .
} 
membantu terlaksanánya penerbitan dan perdagangan $\mathrm{CP}$ dimaksud. Pihak bank akan sangat berperan dalam proses penerbitan dan perdagangan $\mathrm{CP}$.

Meskipun sebenarnya $C P$ adalah surat sanggup dalam wajahnya yang baru, akan tetapi dalam proses penerbitan dan perdagangannya sangat berbeda dengan surat sangup yang dimaksudkan dalam Kitab Undang-Undang Hukum Dagang (KUHD). Dalam surat sanggup hanya ada hubungan hukum dua pihak, yaitu penerbit dan pemegang surat sanggup. Penerbit surat sangup sebagaimana penerbit surat berharga lainnya akan bertangung jawab terhadap pembayaran surat sangup yang diterbitkannya, karena dalam menerbitkan surat sangup memang tidak melibatkan pihak lain. Pada penerbitan CP akan melibatkan pihak bank sebagai pengatur penerbitan (arranger), agen penerbitan (issuing agent), agen pembayar (paying agent), agen penjualan (dealer), bahkan dimungkinkan bank sebagai investor.

Keterlibatan pihak bank dalam penerbitan dan perdagangan $C P$ tentu akan membawa dampak terhadap tanggung jawab yang harus dipikulnya. Bagi para pengguna $C P$ khussusnya para investor sangat perlu mengetahui seberapa jauh tangung jawab bank dalam penerbitan dan perdagangan $\mathrm{CP}$, karena masalah tanggung jawab ini sangat berkaitan dengan jaminan keamanan dana yang akan diinvestasikan dalam CP tersebut. Secara hukum CP adalah surat sanggup, akan tetapi karena $\mathrm{CP}$ memiliki pengaturan sendiri, yaitu dalam Surat Keputusan No.28/52/KEP/DIR (selanjutnya disingkat SK.DIR.BI) dan Surat Edaran Bank Indonesia No.28/49/UPG (selanjutnya disingkat SEBI) tentang Persyaratan Penerbitan dan Perdagangan Surat Berharga Komersial (Commersial Paper) Melalui Bank Umum di Indonesia, masing-masing Tanggal 11 Agustus 1995. Selain itu, berbeda dengan surat sanggup maka dalam proses penerbitan dan perdagangan $\mathrm{CP}$ dibuat suatu perjanjian tertulis antara pihak bank dan pihak penerbit $\mathrm{CP}$, untuk mempertegas hak dan kewajiban serta tanggung jawab masing-masing pihak. Oleh karena itu, dengan adanya kekhususan-kekhususan yang dimiliki CP maka perlu diketahui pengaturan tentang pernerbitan dan perdagangan $\mathrm{CP}$ ini kepada masyarakat, khususnya menyangkut tanggung jawab bank yang terlibat dalam proses penerbitan dan perdagangan $C P$. Untuk itu perlu dilakukan suatu penelitian mengenai tangung jawab bank dalam proses penerbitan dan perdagangan $\mathrm{CP}$.

Berdasarkan latar belakang tersebut di atas dapat diketahui bahwa CP dapat digunakan sebagai alternatif pendanaan perusahaan. Sebagai alternatif pendanaan perusahaan maka setiap pihak yang membutuhkankan dana perusahaan dapat menerbitkan dan memperdagangkan $C P$. Untuk menerbitkan dan memperdagankan $C P$ akan melibatkan bank sebagai pengatur penrbitan (arranger), agen penerbit (issuing agent) dan bank sebagai agen pembayar (paying agent).

Berdasarkan uraian di atas, rumusan masalah dalam penelitian ini adalah bagaiman tangung jawab bank yang terlibat dalam proses penerbitan dan perdagangan $\mathrm{CP}$ ?

Pendekatan yang digunakan dalam menjawab permasalahan adalah yuridis normatif, analisis data secara kualitatif.

\section{B. HASIL DAN PEMBAHASAN}

\section{Pengertian Comercial Paper (Surat Berharga Komersial)}

Kata Commercial Paper sebenarnya merupakan kata-kata dari Bahasa Inggris, yang apabila diterjemahkan ke dalam Bahasa Indonesia menjadi surat perniagaan. Akan tetapi istilah tersebut di Indonesia diterjemahkan menjadi surat berharga komersial, dan dalam dunia usaha dikenal dengan singkatan SBK atau CP. Di luar negeri pada umumnya $\mathrm{CP}$ merupakan unsecured promissory notes di mana penerbit berjanji akan membayar sejumlah uang tertentu kapada saat jatuh waktu. CP diterbitkan untuk keperluan pembiayaan jangka pendek atau modal kerja. ${ }^{3}$

Menurut UCC (Uniforms Commercial Code), Commercial Paper merupakan kumpulan negotiable instruments yang berbentuk Draft, Chek, Certifikat of Deposit dan Notes, ${ }^{4}$ While

\footnotetext{
Dahlan.M Sutalaksana 1994. Perkembangan dan Prospek Commercial Paper Sebagai Alternatif Pendanaan dan Investasi di Indonesia. Makalah dalam Seminar Nasional Tentang Commercial Paper Sebagai Alternatif Pendanaan dan Investasi dan Aspek Hukumnya di Indonesia. Jakarta.

' Sutan Remmy Syahdeini. Beberapa Pokok Pikiran Mengenai Reformasi Hukum Perbankan di Indonesia. Makalah Bahan Kuliah Umum di Fakultas Hukum Universitas Diponegoro Semarang, 1997
} 
the definition of negotiable instruments permits inclusion of wide range of writings that evidience promies or order to pay, the UCC explicitly excludes money, elektronik funs transfer, and securities from coverage in article 3 UCC. ${ }^{5}$ Dalam Black's Law Dictionary (Henry, 1979:245), CP adalah Bill of Exchange (i.e drafts), promissory notes, bank cheks, and other negotiable instruments for payment of money, wich by their from and on their face, purport to be such instrument. UCC Article 3 is general law governing commercial paper. Term includes short term notes issued by corporate borrowers. Syahrir, sebagaimana dikutip Felixs (Felixs, 1994), memberikan pengertian terhadap $\mathrm{CP}$ adalah Indonesian $C P$ is short term prommissory notes issued by solid corporation to meet its short terms liquity need. Masih dikutip oleh Felixs (Felix, 1994), Lamaistre mendefinisikan CP adalah $A$ short term. unsecured promissory notes issued by large. well know and finacially strong corporation (including finance companies) denomination start at USS 10.000 with a maturity date of 270 days or less. Annie (1994), memberi pengertian terhadap $C P$ adalah surat hutang jangka pendek yang bersifat unsecured (tanpa jaminan/ garansi dari bank), diterbitkan oleh perusahaan yang memiliki credit rating tinggi dan dapat diperjualbelikan kepada investor, baik secara langsung melalui perantara/agen, dengan cara perhitungan pokok dan bungan dengan menggunakan sistem diskonto, untuk membiayai modal kerja dan kebutuhan bridge financing perusahaan penerbit

Bertitik tolak dari beberapa pengertian dan definisi CP di atas dapat diketahui bahwa istilah $\mathrm{CP}$ masih memiliki definisi dan pengertian yang berbeda-beda. Di Amerika Serikat CP diartikan sebagai kumpulan surat berharga yang negotiable (dapat diperalihkan), sehingga pengertian CP meliputi Draft, Checks, Certifikat of Deposits (CD) dan Notes. Instrument negotiable adalah secarik kertas yang mempunyai ketentuan sifat formal tertentu, yang membuktikan adanya hutang dari satu orang kepada orang lain. Jika orang menulis instrumen

${ }^{5}$ Clayton Gillete. 1995. Commercial Paper Smith's Review Second Edition. Palmer Evenue: Emanual Law Outline, Inc $\mathrm{him} .2$ itu berjanji untuk langsung membayar hutang, maka instrumen itu disebut sebagai notes. ${ }^{6}$ Notes yang dibuat oleh bank untuk membayar sejumlah uang kepada nasabah tertentu disebut "sertifikat deposito" (CD). Sebaliknya apabila orang menulis instrumen tersebut memerintahkan pihak ketiga misalnya bank, maka instrumen itu disebut sebagai draft, sedangkan cek adalah draft yang dibuat atas bank?

Melihat perkembangan CP di Indonesia yang begitu pesat; sementara masih terdapat berbagai pengertian diberikan terhadap $\mathrm{CP}$; dan dalam kegiatan transaksi CP banyak melibatkan bank sebagai pihak pendukung, maka Bank Indonesia mengeluarkan Surat Keputusan Direksi Bank Indonesia (SK DIR. BI) Indonesia No.28/ 52/KEP/DIR dan Surat Edaran Bank Indonesia (SEBI) No.28/49/UPG tentang Persyaratan Penerbitan dan Perdagangan Surat Berharga Komersial (Commercial Paper) melalui Bank Umumdi Indonesia, masing-masing Tanggal 11 Agustus 1995. Berdasarkan Pasal 1 angka (2) surat SK. DIR, Surat Berharga Komersial (Commercia Paper) dan selanjutnya disebut CP adalah surat sanggup tanpa jaminan yang diterbitkan oleh perusahaan bukan bank, dan diperdagangkan melalui bank atau perusahaan efek, berjangka waktu pendek dan diperdagangkan dengan sistem diskonto. Definisi inilah yang sekarang digunakan untuk memberikan pengertian terhadap CP yang berkembang di Indonesia. Jadi, pengertian $\mathrm{CP}$ di Indonesia tidak sama dengan pengertian $\mathrm{CP}$ di luar negeri, khususnya yang dimuat dalam UCC, di mana CP diartikan kumpulan surat-surat berharga yang negotiable, sehingga tidak saja merupakan surat sanggup (promissory notes), tetapi meliputi draft, $\mathrm{CD}$ dan Check. Istilah CP yang dipergunakan dalam tulisan ini adalah CP sebagaimana dimaksud dalam SK.DIR.BI tersebut

\section{Penerbitan dan Perdagangan CP di Indonesia}

Latar bekang terbitnya suatu surat berharga adalah suatu perjanjian yang disebut

\footnotetext{
"Doglas.J, Whaley, Commercial Paper \& Payment Law, 1992. Giblert Law Sumaries. Fourteen Edition Chicago: Harcourt Brace Legal and Proffesionall Publication, hlm. 2

'Gelarld. J. Thain. A Basic Outline of The Law of Commercial Paper. 1994. Makalah dalam seminar Nasional Tentang Surat Berharga Komersial (Commercial Paper) Dalam Menunjang Bisnis di Indonesia. Bandung.
} 
sebagai perikatan dasar. Perjanjian yang dapat menjadi sebab diterbitkannya surat berhaga adalah perjanjian yang isi prestasinya adalah untuk membayar sejumlah uang. Pembayaran sejumlah uang itu tidak menggunakan uang tunai melainkan menggunakan surat berharga. Pada CP, perjanjian yang melatar belakangi terbitnya $C P$ adalah perjanjian pinjam meminjam uang.

Sebagaimana dijelaskan pada bab pendahuluan bahwa CP dimanfaatkan oleh pengusaha sebagai salah satu alternatif sumber pembiayaan perusahaan, terutama untuk menutupi kebutuhan modal kerja. Jadi, alasan pemanfaatan CP sudah jelas yaitu karena perusahaan (pengusaha) membutuhkan dana untuk membiayai perusahaannya, karena sumber dana lainnya tidak mencukupi. Untuk itu perusahaan membutuhkan para investor yang bersedia menginvestasikan dananya melalui pembelian $\mathrm{CP}$ yang diterbitkan oleh perusahaan yang membutuhkan dana tersebut. CP yang diterbitkan itu akan dijual kepada para investor melalui bank sebagai agen penjual, Harga beli CP adalah merupakan pinjaman dari investor kepada penerbit, di mana hutang itu dijanjikan oleh penerbit akan dibayar kemudian, dan bukti dari pinjaman itu adalah surat CP-nya.

Nono Anwar menjelaskan sebagai berikut: Bahwa dasar pokok dalam CP sederhana sekali, yaitu janji untuk membayar kembali sejumlah hutang yang telah diterima, Janji bayar itu diberikan setelah suatu perseroan, lembaga keuangan atau lembaga lainnya menerima sejumlah uang. Bukti janji itu berbentuk surat promes yang dalam perdagangan disebut $C P$. Jumlah uang yang diberikan disebut "harga beli" CP dan pihak yang membayarnya disebut "pembeli" 8

Dalam CP dapat diketahui jumlah hutang yang harus dibayar kepada investor, karena $C P$ memuat nilai nominal hutang tersebut. Berdasarkan Pasal 1756 KUHPdt, utang yang terjadi karena peminjaman uang hanyalah sejumlah uang yang disebut dalam perjanjian. Dengan diterbitkan dan diserahkannya CP kepada investor, maka hubungan selanjutnya antara penerbit dan investor terikat dengan apa yang tertulis dalam surat CP tersebut. Investor sebagai pemegang surat berharga telah berkedudukan

- Nono Anwar Makarim, Ibid: sebagai orang yang berhak atas sejumlah tagihan dalam CP. Akibat hukum pembubuhan tandatangan penerbit pada $\mathrm{CP}$ adalah penerbit terikat sebagai pihak yang menerima pinjaman sejumlah uang yang tertulis dalam $\mathrm{CP}$ dan berjanji akan mengembalikan pinjaman itu pada tanggal jatuh tempo yang ada pada CP. Jadi, dengan diterbitkannya CP maka penerbit terikat untuk membayar hutang tersebut berdasarkan janji bayar yang dibuat dalam $\mathrm{CP}$.

CP yang telah selesai diterbitkan itu selanjutnya akan di perdagangkan. Dalam dunia usaha perdagangan sering disebut dengan istilah bisnis, padahal perdagangan hanya salah satu dari kegiatan dalam pengertian bisnis. Pengertian perdagangan adalah kegiatan dalam bidang ekonomi yang berupa membeli barang dan menjualnya lagi atau menyewakannya dengan tujuan memperoleh keuntungan dan atau laba. Perdagangan juga dapat diartikan sebagai suatu kegiatan jual beli barag dan jasa, yang dilakukan secara terus menerus dengan tujuan menagih hak atas barang dan jasa yang disertai dengan kompensasi. Jadi, obyek perdagangan sebenarnya bukan hanya barang, akan tetapi dapat berbentuk jasa, dan yang penting bahwa dalam kegiatan itu terkandung perbuatan menjual dan membeli. Pasal 1457 KUHPdt menyebut, perjanjian jual beli adalah suatu perjanjian dengan mana pihak satu mengikatkan diri untuk menyerahkan suatu kebendaan, dan pihak lain untuk membayar harga yang telah diperjanjikan. Dalam kegiatan jual beli terdapat dua perbuatan, yaitu perbuatan membeli dan menjual, dalam Bahasa Belanda disebut koop en verkoop (koop:membeli, verkoop:menjual) ${ }^{10}$

$\mathrm{CP}$ adalah instrumen pasar uang, artinya diperdagangkan di pasar uang (Panji,1996:18). Dalam SEBI No.21/73/UPG tanggal 27 Oktober 1988 tentang Surat Berharga Pasar Uang (SBPU) disebut bahwa SBPU adalah surat berharga jangka pendek dalam rupiah yang dapat diperjual belikan di pasar uang dan dapat berupa: Surat sanggup (aksep/promis) yang diterbitkan oleh nasabah dalam rangka penerimaan kredit dari bank atau LKBB untuk membiayai kegiatan tertentu; dan surat sanggup yang diterbitkan oleh bank atau

\footnotetext{
- Buhori Alma. 1983. Menejemen Pemasyaran dan Pemasaran Jasa Bandung:Alfa Beta. Bandung, hlm.233.

10 H.M.N. Purwosutjipto 1994 Pengerrian Pokok Hukum Dagang Jifid I. Djambatan Jakarta, hlm. I.
} 
LKBB dalam rangka pinjaman antar bank. $C P$ merupakan salah satu surat berharga yang diperjual belikan dipasar uang, meskipun tidak termasuk jenis yang disebut dalam surat edaran tersebut.

\section{Bank Sebagai Pihak Pendukung Dalam Penggunaan Commercial Paper}

Pihak utama dalam $\mathrm{CP}$ adalah penerbit dan pemegang $\mathrm{CP}$ (investor), yang mempunyai hubungan langsung sebagai pihak peminjam dan pemberi dana senilai yang tertulis dalam CP. Dalam proses penerbitan dan perdagangan $\mathrm{CP}$ akan melibatkan bank sebagai pihak pendukung. Keterlibatan bank di sini tentu saja karena usaha bank pada dasarnya adalah suatu usaha simpan pinjam demi dan untuk kepentingan pihak ketiga. Dalam SK Dir. Bl tentang Commercial Paper, bank yang dapat terlibat dalam perdagangan $C P$ adalah bank umum sebagaimana diatur dalam UU Perbankan 1992. Berdasarkan UU Perbankan No. 7 tahun 1992 jo UU No. I 0 tahun 1998 tentang Undang-undang Pengganti Atas UUNo.7 Tahun 1992 tentang Perbankan, bank umum adalah bank yang dapat memberikan jasa dalam lalu lintas pembayaran.

Demikian pentingnya peranan perbankan dalam kegiatan perekonomian pada umumnya, sehingga dalam menjalankan kegiatan usahanya bank selalu dituntut untuk tetap menerapkan asas kehati-hatian." Dalam hal ini bank bank juga harus memperhitungkan bahwa dana yang akan disalurkan kepada pihak lain akan berdampak pada nasabah kreditur, dan oleh karenanya bank harus memperhatikan aspek pengembalian dana yang akan disalurkannya itu (Marulak, 1998:12) Keadaan ini perlu diperhatikan oleh bank, apalagi jika bank langsung terlibat dalam kegiatan pinjam meminjam uang itu, seperti kredit perbankan. Menurut Thomas (1993:61), untuk mengurangi resiko terhadap kegiatannya, maka bank dapat melakukan kegiatan atau aktifitas jual beli surat berharga, dengan cara antara lain menjadi makelar efek atau komisioner efek. Jika demikian berarti bank berkedudukan sebagai lembaga perantara, yaitu sebagai penghubung antara pelaku satu dengan pelaku lainnya untuk mendefisitkan atau

\footnotetext{
"Marpaung Leiden. 1993. Kejahatan Terhadap Perbankan. Eriangga, Jakarta, h/m. 34
}

mendapatkan surplus dari anggaran belanjanya (Soediyono, 1992:4). Keadaan itulah yang terjadi pada bank yang terlibat dalam transaksi $C P$, di mana bank tidak terlibat langsung sebagai pihak dalam perjanjian yang dilakukan dengan pihak pembeli $\mathrm{CP}$, melainkan bank hanya meakukan pekerjaan-pekerjaan yang pada dasarnya merupakan pekerjaan mewakili dan sebagai perantara.

Berdasarkan SK Dir. BI No. 28/52/KEP/ DIR/1995, peranan bank dalam transaksi CP, yaitu sebagai arranger, issuing agent, paying agen dan dealer. Pengatur penerbitan (arranger) adalah bank atau perusahaan efek yang berdasarkan perjanjian tertulis dengan calon penerbit mengatur rencana penerbitan $\mathrm{CP}$. Agen Penerbit (issuing agent) adalah bank atau perusahaan efek yang berdasarkan perjanjian tertulis dengan calon penerbit CP melakukan pengabsahan CP. Agen Pembayar (paying agent) adalah bank yang berdasarkan perjanjian tertulis dengan calon penerbit CP melakukan pembayaran $\mathrm{CP}$ yang sejak $\mathrm{CP}$ tersebut jatuh tempo. Pedagang efek (dealer) adalah bank atau perusahaan efek yang ditunjuk oleh perusahaan calon penerbit $\mathrm{CP}$, mengusahakan penjualan atau pembelian $\mathrm{CP}$, baik untuk kepentingan sendiri atau untuk kepentingan nasabahnya.

Sebagai pihak pendukung dalam proses penerbitan dan perdagangan $C P$, pihak bank melakukan hubungan hukum dengan pihak perusahaan calon penerbit CP. Kemudian dari hubungan hukum tersebut akan memunculkan hak dan kewajiban bagi para pihak dan para akhirnya akan timbul tanggung jawab.

\section{Prosedur Penerbitan dan Perdagangan CP}

Menurut SK, DIR. BI dan SEBI hanya disebut mengenai syarat syarat $C P$ dan para pihak dalam penerbitan dan perdagangan $C P$, sedangkan prosedur penerbitan dan perdagangan $\mathrm{CP}$ tidak diatur. Oleh karena itu, apa yang akan diuraikan dalam bagian ini adalah prosedur pernerbitan dan perdagangan $\mathrm{CP}$ dalam prakrik.

Dalam praktek, Pengatur Penerbitan, Agen Penerbit, Agen Penjual (dealer) dan Agen Pembayar itu dilakukan oleh satu bank, sehingga prosedurnya sebagaimana diuraikan di bawah ini. 
Pengatur Penerbit menghubungi calon penerbit atau sebaliknya: Penerbit akan menghubungi pengatur penerbitan atau sebaliknya untuk lakukan langkah awal, yaitu membuat perjanjian antara perusahaan calon penerbit dengan bank yang akan bertindak sebagai pengatur penerbitan, agen penjual dan agen pembayar, perjanjian itu diberi nama "Perjanjian Penerbitan, Penjualan, dan Pembayaran CP". Dalam perjanjian ini disepakati bahwa perusahaan calon penerbit telah menunjuk bank untuk bertindak sebagai pengatur penerbitan (arranger), agen pembayar (paying agent), dan agen penjual (dealer); dalam hal ini bank menerima penunjukkan tersebut dengan segala persyaratan yang ditetapkan dalam perjanjian ini. Berdasarkan berbagai persyaratan yang ditetapkan itu dapat diketahui bahwa bank baru akan melakukan tugas sebagai pengatur penerbitan jika seluruh persyaratan telah dipenuhi oleh perusahaan penerbit. Dengan demikian, maka langkah selanjutnya bagi perusahaan calon penerbit itu adalah memenuhi segala persyaratan dan kewajibannya berdasarkan perjanjian ini.

\section{Pengatur Penerbitan Menghubungi Lembaga} Pemeringkat: PEFINDO sebagai lembaga pemeringkat efek hanya berhubungan dengan perusahaan calon penerbit dan bukan dengan bank sebagai pengatur penerbitan. Jadi, meskipun yang menghubungi lembaga pemeringkat tersebut adalah bank sebagai pengatur penerbitan, akan tetapi bank tersebut hanya mewakili pihak calon penerbit untuk menyampaikan Surat Permintaan Pemeringkatan.

\section{Lembaga Pemeringkatan menilai} perusahaan calon penerbit: Untuk melakukan penilaian terhadap perusahaan yang akan menerbitkan CP, maka PT.PEFINDO atas permintaan perusahaan yang bersangkutan, melakukan proses pemeringkatan (rating process). Setelah proses pemeringkatan dilakukan maka pernyataan pemeringkat $\mathrm{CP}$ akan disampaikan PEFINDO kepada Pengatur Penerbitan. Pernyataan pemeringkatan tersebut dibuat dalam bentuk Kode Pemerngkatan. Kode tersebut adalah sebagaimana yang dimaksud dalam Surat Edaran Bank Indonesia N0.28/49/ UPG/1995 ditulis dengan urutan PA1 (paling tinggi), PA2 (kuat), PA3 (memuaskan), dan PA4 (memadai).

Pengatur Penerbitan Menerbitkan Memorandum Informasi: Pengatur Penerbitan menerbitkan Memorandum Informasi yang obyektif mengenai perusahaan penerbit sebagaimana dimaksud dalam Pasal 7 Ayat (1) SK Direksi BI No.28/52/KEP/DIR/1995, yang sekurang-kurangnya memuat:
a. laporan keuangan tahun buku terakhir yang telah diaudit oleh akuntan publik yang telah terdaftar di Bapepam dengan kualifikasi wajar tanpa syarat;
b. laporan keuangan kuartalan terbaru;
d. tanggung jawab hukum dari semua pihak yang terlibat dalam transaksi CP;
e. peringkat $C P$.

Berdasarkan Pasal 7 Ayat (2) nya disebut bahwa menyebarluasan Memorandum Informasi tersebut dalam Ayat (1) harus dilakukan melalui media cetak.

\section{Pengatur Penerbitan menghubungi Agen} Penerbitan dan Agen Pembayaran: Karena bank sebagai Pengatur Penerbitan merangkap menjadi Agen Penerbitan dan Agen Pembayaran, maka pengatur penerbitan tidak perlu menghubungi Agen Penerbitan dan Agen Pembayar, melainkan langsung bertindak sebagai Agen Penerbitan dan Agen Pembayaran.

Perjanjian antara Penerbit dengan Agen
Penerbit dan Agen Pembayar: Perjanjian yang dimaksudkan di sini adalah perjanjian yang telah dibuat antara calon penerbit dengan bank, yaitu Perjanjian Penerbitan Penjualan dan Pembayaran, sebagaimana telah dijelaskan di atas. Hal ini adalah karena bank sebagai Pengatur Penerbitan langsung ditunjuk untuk bertindak sebagai Agen Penerbitan dan Agen Pembayaran. Karena perjanjian yang dimaksudkan telah dibuat, maka pada tahap ini agen penerbit melakukan langkah untuk menerbitkan CP. Langkah-langkah yang dilakukan untuk menerbitkan CP ini adalah:

a. Perintah Penerbitan dari Perusahaan Calon Penerbit CP. Setelah persyaratan dipenuhi, termasuk persyaratan pemeringkatan tersebut di atas, maka selanjutnya 
perusahaan calon penerbit CP membuat Surat Perintah Penerbitan yang ditandatngani oleh pihak yang ditunjuk oleh perusahaan atau kuasanya sesuai Kartu Contoh Tandatangan yang ada di bank.kepada bank. Surat Perintah Penerbitan itu berisi informasi mengenai: jumlah outstanding total nominal CP yang akan diterbitkan, sebagimana juga telah disepakati dalam perjanjian antara bank dan perusahaan, tanggal penerbitan, dan tanggal jatuh tempo;

b. Bank akan melengkapi CP yang akan diterbitkan itu berdasarkan konfirmasi yang terdapat dalam Surat Perintah Penerbitan yang diterimanya itu.

c. CP yang telah dilengkapi dengan nilai nominal, tanggal penerbitan, tanggal jatuh tempo dan nomor seri CP, diserahkan kepada perusahaan calon penerbit $C P$ untuk ditandatangani oleh pihak pejabat perusahaan yang berwenang sesuai Kartu Contoh Tanda Tangan yang ada di bank.

d. Pengabsahan $\mathrm{CP}$ oleh bank sebagai Agen Penerbit (Issuing Agent), CP yang telah ditandatangani oleh perusahaan penerbit dikembalikan kembali kepada bank untuk memperoleh pengabsahannya. Bank akan melakukan pengabsahan terhadap CP dengan membubuhkan tanda tangannya dalam $C P$. Untuk melakukan pengabsahan $C P$, berdasarkan SK Direksi BI, bank harus melakukan penelitian kebenaran $C P$ tersebut dari segi administratif dengan memperhatikan antara lain Anggaran Dasar/Anggaran Rumah Tangga perusahaan calon penerbit, kebenaran dan keaslian tanda tangan penerbit $\mathrm{CP}$, keaslian kertas; dan segi yuridis dengan memperhatikan pemenuhan undang-undang dan ketentuan yang berlaku.setelah $\mathrm{CP}$ disahkan oleh bank, maka berarti CP tersebut telah secara sah diterbitkan, dan oleh karenanya maka CP tersebut harus diserahkan kepada bank untuk diatur penjualannya atau disimpan dalam custody bank.

\section{Agen Penerbit menjual kepada investor} pertama secara langsung atau melalui dealer: Karena dalam perjanjian telah disebut bahwa bank juga ditunjuk untuk bertindak sebagai agen penjual (dealer), maka berarti penjualan CP kepada investor yang pertama dilakukan oleh bank sebagai agen penjual (dealer).

\section{Investor Pertama menjual kepada Investor} Kedua dengan cara endosemen blanko dan tanpa hak regres: Cara penjualan dengan endosemen blanko dan tanpa hak regres tersebut telah diatur dalam SK Direksi BI dan SEBI. Selain itu dipertegas dalam kertas CP-nya. Arti dari penjualan dengan cara endosemen blanko dan tanpa hak regres ini adalah bahwa dalam melakukan endosemen untuk memperalihkan CP dari investor pertama kepada investor kedua dan seterusnya dilakukan dengan endosemen blanko. Dengan endosemen blanko pihak yang mengalihkan tidak perlu membubuhkan tandatangan dalam surat CP sebagai tanda peralihan, melainkan cukup dilakukan pemindahan hCP dari tangan ke tangan. Akibatnya pihak yang mengalihkan (endosan) akan terbebas dari regres yang dilakukan oleh pemegang CP. Perdagangan CP ini berdasarkan Pasal 5 SK Direksi Bi No.28/ 52/KEP/DIR/1995 adalah dilakukan dengan sistem diskonto. Sistem diskonto berlaku baik di pasar perdana maupun di pasar sekunder.

Selanjutnya investor kedua atau investor (pemegang) terakhir dari CP menguangkan $\mathrm{CP}$ setelah jatuh tempo kepada agen pembayar. Penguangan kepada Penerbit setelah 6 (enam) bulan sejak jatuh tempo; atau jika Agen Pembayar menolak pembayaran

Menurut ketentuan Pasal 4 Ayat (1) SK Direksi BI No.28/52/KEP/DIR/1995"Bahwa tenggang waktu untuk memintakan pembayaran kepada agen pembayar adalah selambatlambatnya dalam jangka waktu 6 (enam) bulan setelah CP jatuh tempo. Dan berdasarkan ketentuan Pasal 4 Ayat (2) nya disebut bahwa setelah jangka waktu sebagaimana disebut dalam Ayat (1), CP hanya dapat ditagihkan langsung kepada penerbit. Jadi jika setelah lewat waktu 6 bulan sejak jatuh tempo CP belum ditagih kepada agen pembayar, maka pemegang hanya dapat menagih CP tersebut langsung pada penerbitnya. Penagihan langsung kepada penerbitnya juga dapat dilakukan apabila saat ditagihkan pada agen pembayar, ternyata agen pembayar menolak untuk melakukan pembayaran. 


\section{Hubungan Hukum Antara Perusahaan Calon Penerbit CP dengan Bank}

Dalam praktiknya pihak bank yang berkedudukan sebagai pengatur penerbitan, agen penerbit, agen pembayar dan agen penjualan, dipegang oleh satu bank. Antara perusahaan penerbit dan bank dibuat suatu perjanjian dalam suatu akta khusus untuk itu yang disebut "Perjanjian Penerbitan, Penjualan dan Pembayaran CP". Isi perjanjian ini adalah perusahaan penerbit memberi kuasa kepada bank untuk bertindak sebagai pengatur penerbitan, agen penerbit, agen penjualan, dan agen pembayar, sebagai berikut:

a. perseroan bermaksud menerbitkan Promissory Notes (Surat Promes) atau bentuk-bentuk surat berharga lainnya menurut Hukum Negara Republik Indonesia sebagai jenis Commercial Paper;

b. bahwa sehubungan dengan maksud tersebut, perseroan dengan ini menunjuk bank untuk bertindak sebagai Arranger dan Agen Penjualan CP yang diterbitkan tersebut, dan bank menyetujui penunjukkan dimaksud, berdasarkan ketentuan dan syarat-syarat yang disepakati dalam perjanjian ini;

c. bahwa perseroan menunjuk pula bank, untuk bertindak sebagai Agen Pembayaran, dalam kaitannya dengan $\mathrm{CP}$ yang diterbitkan oleh perseroan pada saat jatuh tempo atau sesudahnya dan bank menyetujui penunjukkan dimaksud;

d. bahwa guna lebih menjamin dipenuhinya kewajiban perseroan terhadap investor yang timbul berdasarkan perjanjian ini, oleh perseroan diserahkan jaminan berupa saham.

Berdasarkan hal tersebut di atas dapat diketahui bahwa perusahaan menunjuk dan memberikan kuasa secara tegas bank untuk bertindak sebagai pengatur penerbitan, agen penjualan dan agen pembayar, sedangkan penunjukan dan pemberian kuasa kepada bank sebagai agen penerbit tidak disebut secara tegas, padahal Agen penerbit akan melaksanakan tugas mengesahkan $\mathrm{CP}$ yang akan diterbitkan. Ternyata dalam perjanjian ini yang dimaksud bank sebagai arranger termasuk juga bank sebagai issuing agent (agen penerbit). Hal tersebut dapat diketahui melalui ketentuan Pasal 5 Ayat (1) dan Pasal 6
Ayat (5) huruf (c). Pasal 5 . Ayat (1) menyebut bahwa: perseroan menyetujui bahwa CP yang akan diterbitkan berdasarkan perjanjian ini adalah dalam bentuk dan isi yang disetujui terlebih dulu oleh bank. Kemudian Pasal 6 Ayat (5) huruf (c) menyebut bahwa sebelum penyerahan $\mathrm{CP}$ kepada investor, bank hanya akan mengkonfirmasikan atau mengakui tandatangan pejabat perseroan yang tercantum dalam $\mathrm{CP}$, jika tandatangan tersebut sesuai dengan tandatangan pada kartu contoh tandatangan yang terdaftar pada bank dan konfirmasi bank tersebut bukan dimaksudkan sebagai pengalihan hak CP (endorsement) kepada investor atau pihak ketiga lainnya. Halhal yang ditulis dalam dua pasal tersebut menandakan bahwa perusahaan menunjuk juga bank sebagai agen penerbitan, karena menurut SK DIR BI yang dapat menyetujui atau mengesahkan CP yang akan diterbitkan adalah bank dalam kapasitasnya sebagai agen penerbitan.

Selain berisi pemberian kuasa isi perjanjian juga memuat ketentuan dan persyaratan dalam pelaksanaan kuasa terebut. Isi perjanjian pada dasarnya memuat ketentuan-ketentuan dan syarat-syarat yang telah diperjanjikan oleh pihakpihak. Ketentuan dan syarat-syarat ini berisi hak dan kewajiban yang harus mereka penuhi. Dalam suatu perjanjian biasanya memuat syarat-syarat yang tegas, yang terdiri dari syarat-syarat pokok dan syarat-syarat tambahan; syarat-syarat yang diam-diam; dan klausula penyampingan. Dari syarat yang dengan tegas disebut dalam "Perjanjian Penerbitan, Penjualan dan Pembayaran CP", baik syarat pokok maupun syarat pelengkap dapat diketahui kewajibankewajiban yang bersifat pokok dan hak dari masing-masing pihak. Berikut adalah uraiannya.

\section{Kewajiban Pokok Bagi Perusahaan Calon Penerbit CP}

a. memenuhi seluruh persyaratan yang ditetapkan dalam Pasal 10 perjanjian tersebut;

b. memperoleh hasil pemeringkatan dari PT.PEFINDO;

c. menyerahkan saham yang akan dijadikan jaminan dan menyampaikan Surat Perintah Penerbitan dimaksud kepada bank sebelum penerbitan; 
d. menandatangani $\mathrm{CP}$ yang akan diterbitkan sesuai tandatangan yang terdapat dalam kartu contoh tandatangan yang terdapat di bank;

e. menyerahkan kembali CP yang telah diisi dan ditandatangani kepada bank untuk disahkan dan diterima kembali oleh bank selaku agen penjualan $\mathrm{CP}$;

f. menyampikan surat permohonan penjualan CP kepada bank dalam waktu yang telah ditetapkan dalam perjanjian tersebut;

g. jika perusahaan penerbit menghendaki dihentikannya penawaran dan penjualan $\mathrm{CP}$ oleh bank, perusahaan wajib menyampaikan permintaan penghentian tersebut melalui telepon yang kemudian dikonfirmasikan secara tertulis;

h. menjamin pembayaran CP saat jatuh tempo;

i. menyediakan dana yang cukup pada rekening perusahaan yang ada di bank saat $\mathrm{CP}$ jatuh tempo, selambat-lambatnya pukul 10.00 WIB hari kerja;

j. jika setelah lewat waktu 6 (enam) bulan pemegang tidak menagih pembayarannya pada bank pembayar, maka penerbit wajib melakukan sendiri pembayaran CP yang langsung ditagihkan kepadanya.

\section{Hak -hak Perusahaan Calon Penerbit CP}

a. perusahaan calon penerbit berhak atas fasilitas bank untuk melakukan pengaturan penerbitan, mengesahkan, menjual dan melakukan pembayaran atas CP; yang akan diterbitkannya, setelah calon penerbit memenuhi segala persyaratan yang ditetapkan dalam perjanjian;

b. berdasarkan ketentuan dalam perjanjian, perusahaan berhak untuk memutuskan perjanjian dengan bank dengan memenuhi kewajiban yang ditetapkan dalam perjanjian.

\section{Kewajiban-kewajiban Pokok bagi Bank}

a. setelah menerima dari perusahaan, saham yang akan dijadikan jaminan dan akan diikat dengan gadai dan perusahaan juga telah memngirim Surat Perintah Penerbitan CP, maka bank sebagai arranger wajib menerbitkan CP dimaksud;

b. sebagai issuing agent, bank wajib melakukan pengesahan terhadap CP yang akan diterbitkan dan diperdagangkan tersebut; tetapi tandatangan pengesahan dari bank tidak ditujukan untuk memberikan aval atau jaminan apapun terhadap CP yang disahkannya itu;

c. sebagai dealer, atas nama dan tanggung jawab perusahaan bank melakukan penawaran dan penjualan CP kepada para investor, dan menghentikan penjualan $\mathrm{CP}$ jika ada permintaan dari perusahaan untuk menghentikan penjualan $\mathrm{CP}$ tersebut;

d. sebagai paying agent, bank wajib membayar $C P$ yang jatuh tempo dengan syarat perusahaan telah menyediakan dananya pada rekening perusahaan di bank guna membayar CP tersebut; dan jika pada saat jatuh tempo dana dimaksud belum tersedia maka bank tidak wajib untuk membayarnya terlebih dahulu.

\section{Hak-hak Bank}

a. jika bank telah melakukan segala kewajibannya berdasarkan perjanjian ini, maka bank berhak atas imbalan jasa dari perusahaan sebagaimana disepakati dalam perjanjian, yaitu berupa arrangement fee, selling fee, dan paying agent fee;

b. berdasarkan perjanjian bank berhak untuk memutuskan perjanjian dengan perusahaan dengan ketentuan yang ditetapkan dalam perjanjian ini, yaitu dengan pemberitahuan kepada perusahaan I (satu) bulan sebelumnya;

c. dalam hal pemutusan perjanjian dilakukan oleh perusahaan, maka bank tetap berhak atas arrangement fee yang telah dibayarkan pihak perusahaan kepadanya;

d. berdasarkan perjanjian, bank tetap berhak untuk menuntut perusahaan dikemudian hari jika hak untuk menuntut perusahaan melakukan kewajibannya belum digunakan oleh bank;

e. kealpaan bank untuk minta dilaksanakannya ketentuan-ketentuan dalam perjanjian ini atau untuk menggunakan hak, wewenang, upayaupaya hukum berdasarkan perjanjian ini atau yang diberikan hukum kepada bank, tidak dapat ditafsirkan sebagai pelepasan ketentuan tersebut dan tidak membatasi hak bank untuk menggunakan hak, kewenangan atau upaya-upaya hukum tersebut dikemudian hari. 


\section{Tanggung Jawab Bank dalam Penerbitan dan Perdagangan $\mathrm{CP}$}

Tanggung jawab akan muncul ketika kewajiban-kewajiban tidak dilaksanakan dan hal tersebut akan menimbulkan kerugian. Demikian juga tanggung jawab bank akan muncul ketika apa yang menjadi kewajiban bagi bank tidak dilaksanakan dan kemudian muncul kerugian, baik bagi perusahaan calon penerbit maupun bagi investor, Oleh karena itu, pembahasan mengenai tanggung jawab bank tidak dapat dilepaskan dari pembahasan mengenai kewajiban-kewajibannya, baik sebagai pengatur penerbitan (arranger), agen penerbitan (issuing agent) maupun sebagai agen pembayar (paying agent).

\section{Tanggung Jawab Bank sebagai Pengatur Penerbitan (Arrangger)}

Kewajiban bank sebagai pengatur penerbitan adalah menatalaksanakan dan membantu proses penerbitan CP. Dalam proses tersebut bank membantu calon penerbit untuk mendapatkan peringkat dari PEFINDO, mencari calon investor sampai pada relisasi penerbitan CP. Dalam proses tersebut tidak ada ketentuan yang mengatur mengenai akibat hukum terhadap segala kewajiban yang tudak dijalankan bank. Perjanjian antara bank dan calon penerbit hanya menyebut beberapa kewajiban pokok bank, di mana kewajiban bank sebagai pengatur penerbitan mempunyai kewajiban untuk menerbitkan $\mathrm{CP}$ setelah menerima dari perusahaan, saham yang akan dijadikan jaminan dan akan diikat dengan gadai dan perusahaan juga telah memngirim Surat Perintah Penerbitan CP. Dengan demikian, tidak ada bentuk tanggung jawab bank karena $C P$ diterbitkan atas adanya saham sebagai jaminan dan adanya Surat Perintah Penerbitan CP dari calon penerbit. Surat perintah tersebut tidak akan dilaksanakan oleh bank jika calon penerbit CP belum memenuhi segala persyaratan yang ditetapkan oleh bank dan tertuang dalam perjanjian. Dalam SK DIR.BI dan SEBI tentang Penerbitan dan Perdagangan CP tidak mengatur tanggung jawab bank sebagai pengatur penerbitan, sedangkan dalam perjanjian antara bank dengan calon penerbit dapat diketahui dari ketentuan Pasal 6 Ayat (5) perjanjian, bahwa dalam hal bank betindak sebagai pengatur penerbitan (arranger), maka perseroan menyetujui dan mengikatkan diri bahwa:

a. bank dalam hal ini akan bertindak sungguhsungguh dan sebatas kemampuannya (best efforte) dan tidak mengikat (uncomited);

b. bank tidak bertanggung jawab dan tidak menjamin dalam bentuk apapun atas penerbitan $\mathrm{CP}$ ini, kecuali yang menyangkut tugas bank selaku arranger dan dealer;

c. sebelum penyerahan CP kepada investor, bank hanya akan mengkonfirmasikan atau mengakui tandatangan pejabat perseroan yang tercantum dalam $\mathrm{CP}$, jika tandatangan pejabat tersebut sesuai tandatngan pada Kartu Contoh Tandatangan yang terdaftar pada bank dan konfirmasi tersebut bukan dimaksudkan sebagai pengalihan hak kepada pemegang CP (endorsement) kepada investor atau pihak lainnya;

d. Perseroan akan mengganti kerugian dan melindungi bank dari segala kewajiban, tuntutan-tuntutan, kerugian dan biaya-biaya lainnya yang timbul sehubungan dengan penerbitan CP ini, kecuali terhadap hal-hal yang disebabkan oleh kesalahan bank.

\section{Tanggung Jawab Bank sebagai Agen Penerbitan (Issuing Agent)}

Kewajiban pokok bank sebagai issuing agent adalah melakukan pengesahan terhadap CP yang akan diterbitkan dan diperdagangkan, tetapi tandatangan pengesahan dari bank tidak ditujukan untuk memberikan aval atau jaminan apapun terhadap CP yang disahkannya itu. Hal tersebut dapat diketahui dari ketentuan Pasal 8 SK DIR BI, agen penerbit wajib melakukan penelitian atas kebenaran prosedur penerbitan $C P$, baik dari segi administrattif maupun yuridis. Kemudian dalam SEBI dijelaskan, yang dimaksud dengan hal-hal yang bersifat administratif tersebut adalah penelitian atas kebenaran prosedur penerbitan $\mathrm{CP}$, baik dari segi administratif dengan memperhatikan antara lain Anggaran Dasar/ Anggaran Rumah Tangga perusahaan calon penerbit $C P$, kebenaran dan keaslian tandatangan penerbit $C P$ serta keaslian kertas $C P$ yang bersangkutan; sedangkan hal-hal dari segi yuridis adalah dengan memperhatikan pemenuhan undangundang dan ketentuan yang berlaku. Lebih lanjut dalam SEBI dijelaskan, berkenaan dengan 
pengabsahan atas $C P$ tersebut tidak dimaksudkan untuk melakukan aval atau memberikan jaminan apapun.

Bertitik tolak dari ketentuan tersebut dapat dipahami bahwa meskipun bank sebagai agen penerbitan akan melakukan pengabsahan terhadap CP yang akan diterbitkan dengan cara membubuhkan tandatangan pejabat bank dalam $\mathrm{CP}$ dimaksud, akan tetapi tandatangan pihak bank tersebut tidak dapat diartikan bahwa bank bertanggung jawab terhadap pembayaran $C P$. $\mathrm{Hal}$ ini karena tandatangan bank adalah hanya sebagai bukti bahwa CP sah untuk diterbitkan, sehingga pengabsahan yang dibuktikan dengan tandatangan pihak bank hanya merupakan bukti formal bahwa CP sah untuk diterbitkan dan bukan dimaksudkan memberikan aval atau jaminan apapun terhadap CP tersebut.

Ketentuan dalam SK. DIR. BI dan SEBI tersebut tidak sejalan dengan ketentuan dalam KUHD mengenai kedudukan peenandatangan sepucuk surat wesel. Ketentuan tersebut dapat ibaca dalam Pasal 106 KUHD, apabila surat wesel memuat tandatangan orang yang menurut hukum tidak cakap mengikatkan dirinya dengan menggunakan surat wesel, atau tandatangan palsu, atau tandatangan rekaan belaka, atau tandatangan yang tidak peduli apa yang menjadikan sebabnya tidak dapat mengikat diri mereka yang menaruhnya, atau diri mereka atas nama siapa tandatangan itu ditaruhnya, maka biar bagaimanapun juga ikatan orang-orang lain yang tandatangannya termuat dalam surat wesel itu berlaku juga, Menurut Abdulkadir ${ }^{12}$ menurut pengertian pasal tersebut setiap penandatangan berdiri sendiri-sendiri, ketidakbenaran suatu tandatangan tidak mempengaruhi tandatangan lainnya. Tandatangan satu tidak bergantung pada tandatangan lainnya, jika ada tndatangan yang tidak sah maka tidaklah berarti wesel tersebut tidak sah. Tandatangan yang tidak sah tetap tidak sah akan tetapi tandatangan yang sah tetap sah dan inilah yang berlaku.

Bertitik tolak dari ketentuan Pasal 106 KUHD dan uraian di atas, dapat dipahami bahwa sebenarnya dalam suatu surat berharga mengenal suatu teori bahwa pihak yang tandatangannya terdadapat dalam surat berharga adalah debitur

\footnotetext{
$\overline{17}$ Abdulkadir Muhammad 2003. Hukum Dagang Tenrang Surat-Surat Berharga: Citra Aditya Bakti, Bandung, him.76.
}

dari surat berharga tersebut artinya bertanggungjawab atas pembayarannya. Jadi jika salah satu debitur telah melunasinya maka debitur tersebut mempunyai hak tagih terhadap debitur lainnya, sampai debitur terakhir yaitu penerbit. Tidak demikian halnya dengan tandatangan bank sebagai agen penerbitan dalam proses penerbitan dan perdagangan $\mathrm{CP}$, di mana tandatangan tersebut justru tidak dimaksudkan sebagai pemberian aval atau jaminan apapun terhadap CP. Dengan demikian, tanggung jawab bank sebagai agen penerbit hanya terbatas pada tanggung jawab yang berkaitan dengan pemenuhan persyaratan penerbitan CP, baik secara administratif maupun secara yuridis. Meskipun dalam pengertian umum setiap penandatangan surat berharga adalah debitur, akan tetapi kenyataannya penandatangan $\mathrm{CP}$ sebagai agen penerbit tidak dapat diartikan demikian. Tanggung jawab pterhadap pembayaran $C P$ tetap ada pada pihak penerbit yang menandatangani $\mathrm{CP}$ sebagai penerbit.

\section{Tanggungjawab Sebagai Agen Pembayar (Paying Agent)}

Agen pembayar adalah bank yang berdasarkan perjanjian tertulis dengan perusahaan calon penerbit $C P$ melakukan pembayaran sejak $\mathrm{CP}$ tersebut jatuh waktu. Sebagai agen pembayar, bank wajib membayar CP yang jatuh tempo dengan syarat perusahaan telah menyediakan dananya pada rekening perusahaan di bank guna membayar CP tersebut; dan jika pada saat jatuh tempo dana dimaksud belum tersedia maka bank tidak wajib untuk membayarnya terlebih dahulu. Dalam SK.DIR.BI Pasal 4 ditetapkan, CP yang jatuh waktu dapat ditagihkan sejumlah nilai nominal pada agen pembayar selambatlambatnya dalam jangka waktu 6(enam) bulan sejak jatuh waktu (Ayat 1); setelah jangka waktu tersebut dalam Ayat(1), CP hanya dapat ditagihkan langsung pada penerbit.

Kemudian dalam perjanjian antara bank dan calon penerbit CP ditetapkan pada Pasal 8, untuk melaksanakan pembayaran yang telah jatuh tempo kepada investor, perseroan dengan ini memberikan kewenangan penuh kepada bank untuk membayar CP yang telah jatuh tempo dengan cara mendebet/membebani rekening perseroan yang ada di bank (Ayat 3); dan apabila pada saat jatuh tempo $\mathrm{CP}$, dana yang ada pada 
rekening perseroan tidak mencukupi untuk membayar CP yang telah jatuh tempo, maka bank tidak berkewajiban untuk melakukan pembayaran terlebih dahulu kepada investor tersebut (Ayat4). Untuk kepentingan menyimpan dana hasil penjualan $\mathrm{CP}$ dan membayar $\mathrm{CP}$ yang telah jatuh tempo, maka dalam Pasal 7 perjanjian ditentukan bahwa perseroan diwajibkan untuk mempunyai rekening pada kantor cabang yang ditunjuk menurut ketentuan yang berlaku.

Berdasarkan ketentuan dalam SK.DIR.BI dan perjanjian antara bank dengan calon penerbit $\mathrm{CP}$ tersebut di atas dapat diketahui bahwa bank sebagai hanya mempunyai kewajiban membayar saat jatuh tempo sampai enam bulan kemudian sebelum daluarsa, dan kewajiban itu hanya akan dilaksanakan jika dana penerbit telah disediakan pada bank sesuai waktu dalam perjanjian. Jika saat jatuh tempo ternyata dana penerbit tidak tersedia pada bank, maka bank tidak punya kewajiban untuk membayar terlebih dahulu. Ini artinya, bahwa kewajiban penyediaan dana tetap ada pada penerbit, sedangkan bank tidak bertanggung jawab terhadap pembayaran $C P$ yang saat jatuh tempo ternyata dana yang akan dipergunakan untuk itu belum disediakan pihak penerbit pada bank.

\section{PENUTUP}

\section{Kesimpulan}

Bahwa dalam menggunakan $\mathrm{CP}$ sebagai alternatif pendanaan perusahaan akan melibatkan bank dalam proses penerbitan dan perdagangan CP tersebut. Berdasarkan SK.DIR.BI dan SEBI serta perjanjian antara bank dan calon penerbit $\mathrm{CP}$, bahwa keterlibatan bank dalam proses penerbitan dan perdagangan $C P$ adalah sebagai pihak pendukung dan bukan sebagai pihak yang sebenarnya dalam hubungan hukum pada $C P$. Dalam hubungan hukum antara calon penerbit dengan bank, hanya menimbulkan hak dan kewajiban lain dan bukan hak dan kewajiban dalam masalah pembayaran. Pihak yang sebenarnya dalam $\mathrm{CP}$ hanyalah penerbit $\mathrm{CP}$ dan investor atau pemegang CP. Dengan demikian, tanggung jawab terhadap CP hanya ada pada penerbit, sedangkan bank hanya bertanggung jawab terhadap hal-hal yang berkaitan dengan tugasnya sebagai bank, baik sebagai pengatur penerbitan(arranger), agen penerbit (issuing agent), maupun sebagai agen pembayar (paying agent) dan tidak bertanggung jawab terhadap pembayaran CP jika ternyata saat jatuh tempo $C P$ tersebut tidak tersedia danaya di bank pembayar.

Kelemahan dalam pengaturan ini adalah, pihak pengatur penerbitan yang membubuhkan tandatangannya dalam CP-pun tidak dapat dikategorikan sebagai debitur CP yang bertanggung jawab terhadap pembayaran $\mathrm{CP}$. Hal ini bertentangan dengan ketentuan dalam KUHD, yang pada prinsiipnya mengakui bahwa setiap penandatangan wesel adalah bertanggungjawab terhadap wesel tersebut. Secara umum teori hukum surat berharga dalam KUHD adalah bahwa setiap penandatangan surat berharga merupakan debitur surat berharga yang bersangkutan dan olehkarenanya akan bertangungjwab terhadap pembayaran surat berharga tersebut.

\section{Saran}

Kepada Bank Indonesia selaku pembuat kebijakan di bidang perbankan agar memperbaiki kembali ketentuan yang berkaitan dengan masalah penerbitan dan perdagangan $C P$, sehingga tidak terkesan bank hanya akan menagambil keuntungan dari pemberian jasa dalam kegiatan penerbitan dan perdagangan $C P$. Bank Indonesia dapat membuat ketentuan sedemikian rupa, di mana bank juga akan membantu memberikan perlindungan kepada investor yang mengalami kerugian akibat tidak terbayarnya $\mathrm{CP}$ oleh penerbit saat jatuh jempo. Demikian juga dalam pembuatan perjanjian dengan calon penerbit $\mathrm{CP}$, hendaknya dibuat klausul yang mencerminkan adanya tanggungjawab bank untuk memberikan perlindungan hukum kepada investor

\section{DAFTAR PUSTAKA}

Anoraga, Panji dan Niniek. 1994. Pasar Modal Keberadaan dan Manfaatnya Bagi Pembangunan. Rineka Cipta. Jakarta.

Buhori, Alma. 1983. Menejemen Pemasyaran dan Pemasaran Jasa. Alfa Beta. Bandung. 
Campbell, Henry, 1979. Black's Law Dictionary.

Six Edition. Paul Min:-Publishing. Co

Clayton, Gillete. 1995. Commercial Paper Smith's Review. Second Edition. Palmer Evenue: Emanual Law Outlaine, Inc.

Doglas.J, Whaley. Commercial Paper \& Payment Law. 1992. Giblert Law Sumaries. Fourteen Edition. Chicago: Harcourt Brace Legal and Proffesionall Publication.

H.M.N. Purwosutjipto, 1994. Pengertian Pokok Hukum Dagang. Jilid I. Jakarta: Djambatan

Hartono, Sri Redjeki. 1997. Hukum Asuransi dan Perusahaan Asuransi. Grafika. Jakarta.

Marpaung, Leiden. 1993. Kejahatan Terhadap Perbankan. Erlangga. Jakarta.

Manulang. 1994. Pengantar Ekonomi Perusahaan. Liberty. Yogyakarta.

Muhammad, Abdulkadir. 2003. Hukum dagang Tentang Surat-Surat Berharga: Citra Aditya Bakti. Bandung.

- 2005. Hukum Perusahaan Indonesia. Citra Aditya Bakti. Bandung.

Pardede, Marulak. 1998. Likuidasi Bank dan Perlindungan Nasabah. Pustaka Sinar Harapan. Jakarta

Prayitno, Sudiyono Rekso. 1992. Prinsip-Prinsip Dasar bank Umum dan Penerapannya di Indonesia. Jakarta:BPFE

R. Subekti dan R. Tjitrosudibio. 1995. Kitab Undang-Undang Hukum Perdata. Terjemahan. Pradnya Paramita. Jakarta. 1993. Kitab Undang-Undang Hukum dagang. Terjemahan. Pradnya Paramita. Jakarta.

Soemitro, Ronny Hanitijo. 1994. Metodologi Penelitian Hukum dan Jurimetri. Ghalia Indonesia. Jakarta.

Suyatno, Thomas. et. al. 1993 Kelembagaan Perbankan. Gramedia Pustaka Utama, Jakarta.

Annie Woworuntu. 1984. Perkembangan Commercial Paper Dalam Praktek dan Pengaturannya. Makalah dalam Seminar Nasional Tentang Surat Berharga Komersial (Commercial Paper) Dalam Menunjang Bisnis di Indonesia. Bandnung.
Dahlan.M. Sutalaksana. 1994. Perkembangan dan Prospek Commercial Paper Sebagai Alternatif Pendanaan dan Investasi di Indonesia. Makalah dalam Seminar Nasional Tentang Commercial Paper Sebagai Alternatif Pendanaan dan Investasi dan Aspek Hukumnya di Indonesia. Jakarta.

Felixs Subagio. 1994. Beberapa Aspek Hukum Commercial Paper. Makalah pada Seminar Nasional Tentang Surat Berharga Komersial (Commercial Paper) Dalam Menunjang Bisnis di Indonesia. Bandung.

Gelarld. J. Thain. 1994. A Basic Outline of The Law of Commercial Paper. Makalah dalam seminar Nasional Tentang Surat Berharga Komersial (Commercial Paper) Dalam Menunjang Bisnis di Indonesia. Bandung.

Nono Anwar Makarim, 1993. Aspek Hukum Commercial Paper di Indonesia. Makalah pada seminar Nasional Tentang Tinjauan Hukum Atas Commercial Paper. Semarang.

Syahdeini, Sutan Remmy. 1997. Beberapa Pokok Pikiran Mengenai Reformasi Hukum Perbankan di Indonesia. Makalah Bahan Kuliah Umum di Fakultas Hukum Universitas Diponegoro Semarang.

Surat Keputusan Direktur Bank Indonesia No. 28/ $32 /$ KEP/ DIR Tentang Persyaratan Penerbitan dan Perdagangan Surat Berharga Komersial (Commercial Paper) Melalui Bank Umum di Indonesia.

Surat Edaran Bank Indonesia No.28/ 49/ UPG Tentang Persyaratan Penerbitan dan Perdagangan Surat Berharga Komersial (Commercial Paper) Melalui Bank Umum di Indonesia.

Perjanjian Penerbitan, Penjualan dan Pembayaran Commercial Paper Antara Calon Penerbit Commercial Paper dengan Bank Indonesia 46 (Persero) Tbk. 